\title{
CONSIDERAȚII PRIVIND TEATRUL TÂRGUMUREȘEAN ÎN PERIOADA COMUNISTĂ
}

\author{
Maria-Magdalena Florea
}

DOI 10.46522/CT.2021.02.03

\begin{abstract}
Considerations Regarding the Theatre of Târgu Mureș in the Communist Period
\end{abstract}

There are a multitude of artistic directions that manifested themselves in the twentieth century in Romanian culture. This study presents, in short, the social and political framework in which the Târgu Mureș theater evolved during the Ceaușescu dictatorship. Thus, the period 1965-1971 is known as the period of cultural openness and political liberalization. The national veins of culture are rediscovered and revalued; art and cultural activities claim and gain relative autonomy from official policy directives, and ideological censorship becomes more permissive. Literature, theater, cinematography, cultural press, but also the visual arts, know a renewal of substance and performance achievements. After 1971, in the era of the cultural revolution imported from China and North Korea, the communist regime showed an increasing tendency to re-ideologize the cultural environment and tighten censorship. The political regime is gradually evolving towards a restalinization, by imposing an "ideological line" in culture and by the cult of the personality of the dictator Ceausescu. The effect of this ideological turn will prove to be culturally contradictory.

\section{Keywords:}

Theater of Târgu Mureș, Ceaușescu dictatorship, censorship 
Motto:

„Prima noastră datorie astăzi este să ne amintim de toți cei care au murit pentru independența și libertățile noastre, in toate războaiele pe care a trebuit să le ducem și în evenimentele din Decembrie 1989, care au dărâmat dictatura comunistă. Nu putem avea viitor fără a respecta trecutul nostru. "

\section{Considerații privind cultura și civilizația secolului XX}

$\hat{\mathrm{I}}$

nceputul secolului al XX-lea în Europa a însemnat debutul epocii celei mai fertile din ultimii două mii de ani de civilizație, dar și a celei mai violente din punct de vedere politic. Progresele în știință și tehnică au fost umbrite de criza de conștiință a europenilor, legată de afirmarea și consolidarea naționalismelor.

Afirmarea valorilor culturii a avut loc pe fondul dezvoltării economiei care, implicit, a dus la creșterea produsului social și la prosperitatea întregii societăți. Chiar dacă revoluția industrială a adus cu sine concentrarea bogăției în posesia unor grupuri de interese, toate societățile dispuneau de posibilități financiare pentru a aloca resurse activităților creatoare și, pentru prima dată în istorie, i se dădea culturii o importantă funcție socială.

Invențiile și inovațiile din sfera științei au făcut posibile diversificarea și înmulțirea mijloacelor de informare, prin presa scrisă și tipărirea de cărți. Modernizarea societăților s-a reflectat și în sfera culturii, prin marile descoperiri științifice sau prin explorarea noilor teorii din domeniul științelor naturii. S-au făcut progrese extraordinare în domeniul fizicii nucleare, al biologiei celulare, chimiei etc. S-au făcut descoperiri semnificative în domeniul științelor medicale, în combaterea unor boli grave, în special a celor contagioase.

Schimbarea modului de raportare a omului la natură și societate a adus cu sine, în planul cunoașterii socio-umane,

1. Extras din discursul istoric al Regelui Mihai I al României susținut în fața Parlamentului în 25 octombrie 2011, la împlinirea vârstei de 90 de ani. 
schimbarea de mentalitate către direcțiile deschise de psihanaliză și de filosofia bergsoniană, antiintelectualistă.

Colonizarea de către marile puteri europene a unor state din Asia și Africa, dar și decolonizarea înfăptuită după cel de al Doilea Război Mondial au avut efecte majore asupra istoriei secolului al XX-lea. Dominația colonială a însemnat, desigur, de asemenea, dominație politică și economică a „omului alb“ față de rase afro-asiatice, considerate inferioare. J. S. Huxley și A.C. Haddon, în studiul We Europeans: A Survey of „Racial“ Problems (Noi, europenii. Un studiu al problemelor „rasiale“, Londra, New York, 1936) susțineau, alături de alți cercetători britanici ai vremii, că nu există „rase pure“ în Europa și că era mai important mediul în modelarea unei identități comune, iar superioritatea rasială ar fi, în acest context, un mit periculos. ${ }^{2}$

Perioada interbelică a însemnat inflație, instabilitate monetară, datorii externe, o Europă divizată pe plan politic și ideologic. Această dezagregare ideologică se reflectă și în plan cultural, prin confruntarea noilor curente artistice expresioniste sau suprarealiste cu noua ierarhie a valorilor morale și culturale tradiționale.

Urmările celei de a doua conflagrații mondiale sunt reflectate de curentul existențialist, care marchează trecerea la o epocă în care fiecare individ se angajează în lupta pentru cauza generală a umanității. Scena Europei din cea de-a doua jumătate a secolului al XX-lea arată două lumi, divizate de „Cortina de Fier“: o Europă de Vest prosperă și una de Est aflată sub autoritatea politico-ideologică și militară sovietică. Marile puteri coloniale, cu excepția U.R.S.S., își pierd imperiile, iar perioada „Războiului Rece“ se caracterizează printr-un proces de sărăcire. Totuși, Franța, Germania de Vest și Italia reușesc să-și asigure prosperitatea individuală. Se produce un reviriment al producției industriale, care asigură creșteri economice miraculoase. Criza petrolului din anul 1974 a produs un dezechilibru care s-a reflectat și la nivel european prin creșterea șomajului și a inflației într-un ritm galopant.

2. Apud Mark Mazower, Umbre peste Europa. Democrație și totalitarism în secolul XX, traducere din limba engleză de Mihnea Gafița, București, Editura Litera, 2019, pp. 189-190. 


\section{Unitate în diversitate. Între modernitate și specifici- tate culturală}

Realizarea unei Europe unite e de dată mai veche. Prima încercare a eșuat după Primul Război Mondial. Ideea a fost relansată în 1955, la Messina, în Sicilia, când șase miniștri ai afacerilor externe din Comunitatea Europeană a Cărbunelor și Oțelului (Franța, Italia, R.F.G., Belgia, Olanda și Luxemburg) au creat Comunitatea Economică Europeană, la care au aderat ulterior și alte țări. Această comunitate economică de interese s-a transformat odată cu realizarea și a unei comunități politice prin alegerea unui Parlament european și prin adoptarea monedei unice (euro), în anul 1999.

România s-a desprins din blocul socialist în anul 1964, prin afirmarea independenței sale de către Partidul Comunist Român. Schimbările care vor urma în toate țările socialiste sunt accelerate de noua direcție de reformare a societății sovietice prin restructurare economică și democratizare, care i-au fost imprimate din anul 1989.

Realizarea unui sistem de integrare economică a tuturor țărilor europene într-o comunitate este un obiectiv strategic pe termen lung și o provocare demnă de secolul al XXI-lea, când se afirmă, mai mult ca oricând, necesitatea conservării civilizației europene prin păstrarea diversității entităților ei etnoculturale.

Există o multitudine de valori și direcții artistice care s-au manifestat în secolul al XX-lea. Nu există limite precise care să contureze riguros curentele și tendințele în care s-au conturat artele. Întrucât mișcarea artistică a acestui secol este extrem de diversă, exegeții acestui fenomen au păreri controversate în tentativa de a emite sinteze despre cultura contemporană.

Ca exemplu, la debutul secolului al XX-lea, modul în care era percepută vechea pictură a fost detronat mai întâi de industria cinematografică, apoi de designul industrial și, în cele din urmă, de arhitectură. Folosirea unui număr limitat de materiale, impusă de considerente economice, desigur, a condus la o estetică minimalistă, uniformizată, care renunța la elementele decorative în favoarea proporțiilor. Astfel că moderniștii, cei care construiau blocuri-turn sau zgârie-nori 
din oțel și sticlă, nu se mai considerau simpli constructori, ci adevărați artiști și modelatori ai societății.

Modernitatea și specificitatea culturii se manifestă în direcțiile gândirii moderne și concepțiile estetice din acest secol XX, care pledează pentru egalitatea și fraternitatea oamenilor, indiferent cărei rase îi aparțin: albă, galbenă sau neagră. De aceea, exegeza unei opere de artă se cere făcută ținând seama de contextul geografic, de afinități etnice, în corelație cu celelalte științe umane care-i conferă valoare.

În toate ipostazele sale, arta a reprezentat, alături de știință, în secolul XX, cea de a doua activitate esențială a omului. Ea este un mijloc de exprimare care revelează interiorul ființei umane în raport cu mediul existențial. Arta, o spune istoricul și criticul de artă Élie Faure, este acțiune, iar această acțiune, la rândul ei, modelează civilizația. El constata că „fiecare generație adaugă poemului un alt cânt, compus nu numai în graiul pe care ne-am deprins să-1 numim Poezie, Muzică, Pictură, Sculptură sau Arhitectură, ci și cu cel numit de obicei, Acțiune“ (Faure 1990, 10-11). Dar arta poate fi creatoare sau distructivă, precum dragostea dintre oameni, deoarece și ea este un mare transformator de vieți omenești. În sensul celor de mai sus, cultura în secolul al XX-lea și, implicit, artele trebuie înțelese ca acțiuni umane continuatoare ale tradițiilor umaniste ale culturii europene din secolele anterioare.

\section{Cenzură și totalitarism în perioada comunistă}

Dincolo de istoricul textelor sau de tematica abordată, dincolo de viziunea regizorală, literatura dramatică și spectacologia din perioada comunistă 1965-1989, fie că s-a supus, fie că s-a opus presiunii ideologice, a fost evident influențată de un fenomen care s-a manifestat pe tot parcursul acestei perioade de totalitarism: cenzura.

Așadar, înainte de a ne lansa în discuția propriu-zisă, se impune o scurtă explicitare a ce anume înțelegem prin cenzură. Conform Dicționarului explicativ al limbii române, cenzura este controlul exercitat de autoritățile publice, religioase sau politice, asupra vieții private a cetățeanului: asupra 
bibliotecilor, editurilor, publicațiilor, presei, manifestărilor spectacologice, producțiilor cinematografice, televiziunii, internetului și mai nou a platformelor de socializare, cu scopul de a împiedica răspândirea unor idei socotite primejdioase, vulgare, imorale sau chiar revoluționare. (O particularitate a cenzurii este și acea funcție psihologică identificată de Freud și care presupune refularea în inconștient a dorințele neconforme cu convențiile sociale.)

În cartea sa Cenzură și ideologie in comunismul real, scriitorul Dan Culcer face o apreciere inedită referitoare la tema aflată în discuție: „«Cine controlează prezentul controlează trecutul.» Această parte a unei formule orwelliene ${ }^{3}$ definește exact ideologia cenzurii, constituită la intersecția unor programe teoretice cu cele pragmatice, la baza politicii culturale comuniste (marxiste, leniniste, staliniste, dejiste, ceaușiste etc.), în toate variantele localizate pentru Europa de Est, fără excepții. Diferențele au fost de intensitate și cuprindere, de natură tactică, niciodată de natură strategică. Nu ideologia comunistă a indus cenzura, ci chiar cenzura a fost esența ideologiei comuniste, derivată din natura sa utopică și totalitară, ceea ce impunea controlul global, coerența fără falii, niciodată atinsă." (Culcer, 2016, 23) (Dacă în primii ani de comunism Direcția Generală a Presei și Tipăriturilor își exercita controlul numai asupra presei și tipăriturilor, după 1965 sunt cuprinse în sfera sa de control toate mijloacele de propagandă și informare, bibliotecile, editurile, presa, teatrul, filmul și televiziunea).

Pentru Czesław Miłosz, Noua Credință $\breve{a}^{4}$ acea magie exercitată de doctrina comunistă asupra atâtor intelectuali din însângeratul și absurdul secol XX, a însemnat demistificarea

3. George Orwell (pseudonimul lui Eric Arthur Blair) (1903-1950) a fost un scriitor englez care în romanele sale a denunțat teroarea regimurilor totalitare. Le înfățișa într-un univers grotesc, monstruos sau terifiant și pleda pentru libertatea spiritului și demnitatea umană (vezi alegoria Ferma animalelor sau utopia politică negativă 1984).

4. Vezi Czesław Miłosz, Gândirea captivă, scrisă în anul 1953 la Paris. După decizia sa de a rupe cu dictatura comunistă din Polonia și de a rămâne în Vest, eseul lui a devenit un document esențial al literaturii antitotalitare. 
totalitarismului, a faptelor de violență, a abdicării rațiunii și a ascensiunii unor dictatori paranoici pentru care jocul iresponsabil cu destinele a milioane de oameni era răspunsul la ceea ce ei considerau a fi ,comandamentele istoriei“.

Pentru toate țările central și est-europene, ca și pentru România, istoria acestui ,însângerat și absurd secol XX“ a înregistrat două fenomene traumatice din punct de vedere social și politic: 1945 și 1989. Aceste două momente din istorie au presupus nu doar imense pierderi de vieți omenești și valori culturale, dar și adaptarea la alte sisteme de valori decât cele tradiționale.

Schimbarea politică, care a debutat în martie 1945, odată cu instalarea regimului Petru Groza, a cunoscut, timp de doi ani, o perioadă de tranziție, în care nonvalorile noii ideologii au pătruns forțat în conștiința populației românești, sărăcită total în urma războiului, căreia i se promitea un viitor luminos. Evenimentele au evoluat rapid, perioada de „acomodare" finalizându-se prin actul de abdicare forțată a regelui Mihai, la 30 decembrie 1947, și prin adoptarea noii Constituții din aprilie 1948, care a anulat pluralismul politic, a consacrat acapararea completă a puterii de către forțele comuniste și instaurarea regimului de „democrație populară“.

În linii mari, sub raport istoric, putem deosebi trei perioade relativ distincte ale regimului comunist din România: dogmatismul stalinist din anii '50, epoca de relativă liberalizare, între 1964-1971 și epoca de restalinizare, până în 1989.

În plan cultural, regimurile comuniste care au preluat puterea în țările Europei centrale și de răsărit și-au fixat ca obiectiv distrugerea elitei intelectuale, desfigurând cultura națională a țărilor respective și înlocuind-o cu ,una nouă“ sub deviza ,internaționalismului proletar“"

Specificul primei etape a fost determinat de regimul politic de tip fundamentalist și de sovietizarea impuse de Stalin în România și în celelalte țări din blocul socialist. Literatura,

5. În ideologia marxistă, internaționalismul proletar reprezenta un principiu fundamental care exprima unitatea și solidaritatea de clasă internațională a oamenilor muncii din toate țările în lupta împotriva exploatării și asupririi. 
inclusiv cea dramatică, are, în acest timp, o singură dimensiune: „de propagandă și de agitație“, fiind învestită cu misiunea istorică de a exprima, de a transmite și de a impune ideologia de partid. Încadrată într-o concepție unică despre artă, dictată și hotărâtă la Moscova, această literatură trebuia să creeze suportul mental și afectiv necesar înregimentării populației în slujba idealului comunist. Pentru a denumi acest tip de literatură, au fost preluate două formule din Uniunea Sovietică: proletcultism ${ }^{6}$ și realism socialist ${ }^{7}$.

Anul 1948 a fost unul cardinal și pentru cultura României, trecându-se la o politică sistematică de comunizare, îndeosebi prin legea naționalizării, sub efectul căreia au căzut și instituțiile de cultură. În plan politic și cultural, a început o represiune agresivă față de reprezentanții vechii clase politice și intelectuale, în paralel cu un program de sovietizare a culturii. În același an, cenzura ideologică s-a instituționalizat, cu efecte asupra tuturor domeniilor de creație sau de activitate culturală. Au fost stabilite liste cu publicații, opere sau autori care pot vedea lumina tiparului și liste cu publicații

6. Proletcultismul este un termen aplicat literaturii române ideologizate din perioada stalinistă, în comentariile și analizele ulterioare acestui interval de timp. La origine, termenul se referă la organizația Proletcult (,cultura proletară“), organizație „muncitorească cultural-educativă cu caracter de masă“, înființată în Rusia, în 1917, cu puțin timp înainte de Revoluția din Octombrie. Proletcult își declară autonomia față de ideologia leninistă, în numele unei arte „noi“, fără tradiție, fără moștenire, fără continuitate, având caracter mai mult avangardist. Devenind incomodă, organizația este lichidată în anul 1932.

7. Realismul socialist desemnează concepția de tip doctrinar despre artă, oficial transformată în directive, impusă în 1932 de către Partidul Comunist al Uniunii Sovietice, odată cu lichidarea Proletcultului. Realismul socialist impune altă relație cu trecutul: ,preluarea critică și creatoare a celor mai valoroase cuceriri", în folosul societății și al culturii socialiste, și eliminarea elementelor retrograde ale vechii societăți, cea burgheză, pe baza unui spirit critic ascuțit. Conținutul acestei arte se prezintă sub două fațete: pe de o parte, este o critică a trecutului, adică a tarelor moștenite de societatea burgheză, pe de altă parte, este o afirmare a noului care se naște din dezvoltarea socialistă. Promotorii ei susțin că, spre deosebire de arta burgheză, care copiază realitatea, realismul socialist dă artei valoare de sinteză și capacitate de proiecție. 
și opere care trebuiau interzise, cu autori care trebuiau scoși din circuitul public ${ }^{8}$. Bibliotecile publice au fost „purificate“ de lucrările interzise, dar au fost invadate de traduceri din literatura rusă. Filmele rusești au umplut ecranele, iar editurile și ziarele au fost trecute sub un sever control ideologic.

În această perioadă, au avut loc acțiuni de exterminare a elitei, îndoctrinare a populației, ca și impunerea unui model de gândire străin de tradițiile noastre naționale, ideologizarea culturii, a literaturii, a presei, a artei, și s-a dispus izolarea aproape totală de fenomenul cultural european.

În domeniul teatrului, mai întâi, s-a impus modificarea repertoriului cu ajutorul cenzurii. Unii actori au fost criticați, cerându-li-se o mai mare apropiere de public, iar regizorilor li s-a impus traducerea pe scenă a realităților sociale cotidiene. Epurările au fost efectuate prin Direcția Generală a Teatrelor (înființată în anul 1945) de la Ministerul Artelor. Un lucru bun a fost totuși acela că s-au luat măsuri pentru ridicarea unor teatre noi în provincie sau în cartierele muncitorești, care să demonstreze setea de frumos a proletariatului, dar și capacitatea sa de creație teatrală, prin încurajarea turneelor unor formații de amatori, de regulă sindicale (Bușe, Marinescu și Rădulescu-Zoner 1995, 74-75).

Nicolae Cocea, aflat la conducerea Direcției Generale a Teatrelor în iulie 1947, a făcut posibilă apariția Legii nr. 265 pentru organizarea Teatrelor, Operelor și Filarmonicilor de Stat ${ }^{9}$,

8. În 1946, apare catalogul Publicații scoase din circulație, cu 1863 de titluri, dintre care 762 în limba română, iar, în 1948, alt catalog de 10000 de titluri, de 522 de pagini, cu un supliment de 11 de pagini, la care se adaugă toate manualele școlare de dinainte de 1947. Alți autori au fost scoși din circulație prin interdicția tacită de a nu mai fi publicați (ex. Maiorescu, Călinescu). S-au întreprins acțiuni de epurare a bibliotecilor particulare cu arderea sau confiscarea cărților, așa cum s-a întâmplat cu biblioteca lui E. Lovinescu. Scena literară a timpului este copleșită de subliteratură, un rol important în asigurarea alinierii ideologice avându-l critica literară, care devine un fel de jandarm al Partidului. Totuși, excepțiile nu lipsesc, în acestă perioadă apărând câteva romane importante pentru literatura română: Bietul Ioanide de G. Călinescu (în 1953), Moromeții, volumul I, de Marin Preda (în 1955) Cronică de familie de Petru Dumitriu (în 1956), Groapa de Eugen Barbu (în 1957).

9. V. Monitorul Oficial nr. 162/18 iulie 1947, Partea I, A, disponibil 
precum și pentru regimul spectacolelor publice (inițiată de guvernul Petru Groza și adoptată de Adunarea Deputaților) și a elaborat Directivele pentru alcătuirea repertoriilor teatrale, împreună cu Ion Pas, ministrul Artelor. Directivele impuneau respectarea obligatorie a 45 de condiții, ceea ce însemna o gravă limitare a libertății de creație și exprimare dramaturgică, o ignorare a criteriilor tradiționale (profesionalism, talent), o promovare a pseudovalorilor, a rigidității și anostului și, nu în ultimul rând, o aspră cenzură și autocenzură a scenariștilor, regizorilor și actorilor.

Repertoriul era alcătuit ținând seama de niște principii riguroase, preocuparea de bază fiind eliminarea oricărei posibilități de a propaga idei ostile sistemului ori de a prezenta puncte de vedere diferite de cele ale politicii oficiale:

a) îndeosebi până la jumătatea anilor' 60 ai secolului trecut, repertoriul trebuia să conțină lucrări care să prezinte lupta și realizările celui mai înaintat proletariat din lume, evenimentele istorice care au dus la constituirea statului sovietic, să popularizeze activitatea și realizările oamenilor sovietici, ca îndreptar pentru toți oamenii muncii;

b) repertoriul era menit să ofere informații asupra evoluției conștiinței sociale în diversele etape ale dezvoltării istorice;

c) repertoriul trebuia să facă educație estetică, prezentând doar evoluția ideii de frumos, de la o operă la alta și de la un creator la altul;

d) repertoriul urma cu necesitate să prezinte critic tarele societăților trecute, să facă educație patriotică prin popularizarea marilor evenimente și figuri ale istoriei naționale, în cazul nostru să evidențieze fondul clasic al dramaturgiei românești progresiste, ca bază pentru noua dramaturgie socialistă;

e) repertoriul trebuia să sprijine acțiunea de transformare socialistă a țării, aducând în scenă eroii ,autentici“ și problemele majore ale construcției socialiste și să promoveze doar pe acei dramaturgi străini ale căror opere nu puneau în primejdie integritatea „lagărului socialist";

online la: https://upload.wikimedia.org/wikipedia/commons/b/b1/ Monitorul_Oficial_al_României._Partea_1_1947-07-18,_nr._162.pdf 
f) repertoriul era chemat să abordeze teme cu specific regional și local, apropiate de problemele locale ale construcției socialiste, dând astfel un profil propriu unui teatru regional.

Pe bună dreptate, G. Millian deplângea în Semnalul noua lege și directivele adiționale care făceau imposibile reprezentațiile pieselor lui Caragiale pe motiv că ar încălca minimum două condiții/directive: ar jigni bunele moravuri și ar tulbura armonia socială (Selejan 1993, p. 42).

În 3 decembrie 1947, N. D. Cocea era înlocuit în funcția de director general al teatrelor cu regizorul Aurel Ion Maican care, în prima sa conferință de presă, a declarat că nu se va limita doar la aprobarea sau respingerea unor piese, ci va urmări „felul în care spectacolul este pus în scenă și felul în care este interpretat de actori“. Cu același prilej, activistul Ion Negreanu vorbea despre reorganizarea Direcției „potrivit principiului centralismului democratic și muncii de colectiv“ (Bușe, Marinescu și Rădulescu-Zoner 1995, 239-240). Modelul era, bineînțeles, teatrul sovietic, „trecutul de factură realistă“, „,combativ“, „,esențialmente creator“, „esențialmente dinamic“, „teatrul nou“, cu totul diferit de vechiul teatru burghez, cu scop afacerist, „teatrul metafizic“, „retrograd“, „lipsit de talente“ (exemplul negativ dat era situația teatrului din SUA, unde „artiștii sunt concediați, iar teatrele se închid“). Etalonul în regizarea pieselor de teatru era considerat Konstantin Sergheevici Stanislavski (pseudonimul lui K. S. Alekseev, 1863-1938), regizor, actor, pedagog și teoretician de teatru sovietic, iar dintre lucrările lui teoretice erau preferate Viața mea în artă și Munca actorului cu sine însuși $i^{10}$.

Experiența sovietică era permanent elogiată, unii profesioniști ai scenei românești (și privilegiați ai regimului, totodată), precum regizorul Dinu Negreanu, fiind trimiși în vizită în URSS „pentru a urmări activitatea instituțiilor de învățământ artistic, a teatrelor, mișcării muzicale și plastice“, cu această ocazie vizionând zeci de spectacole, participând la audiții, expoziții, lecții, ateliere, conferințe și repetiții. ${ }^{11}$

10. A se vedea Mic dicționar enciclopedic, ediția a III-a, revăzută și adăugită, București, 1986, pp. 1651-1652.

11. Gabriel Catalan, Teatrul și muzica din România în primii ani de 
Regizorii erau criticați pentru că „n-au știut niciodată să fie formatori de spectacole“, axându-și piesele în jurul actorilor principali și părăsind conținutul textului. Li se cerea acestora să fie onești față de popor, fiindcă regizorul este un cetățean și, în primul rând, un ideolog. Era aspru criticată lipsa totală a luptei de clasă.

Rolul secretarului literar era esențial în structura fiecărui teatru, printre atribuțiile acestuia numărându-se principalele sarcini administrative și organizatorice ale stabilirii repertoriului (și, deseori, a distribuției), ale pregătirii, promovării, montării și desfășurării spectacolelor, inclusiv îndrumarea, coordonarea și controlul autorilor, ale traducătorilor, regizorilor, scenariștilor, actorilor și chiar ale spectatorilor, motiv pentru care „era considerat garantul respectării cerințelor politico-ideologice" și al unei stricte autocenzuri în arta dramatică.

Ca în cazul cinematografelor, exista un plan de încasări care trebuia realizat și acest lucru se făcea aproape în exclusivitate prin vânzarea obligatorie a biletelor în întreprinderi și instituții. De cele mai multe ori, publicul era format din soldați și studenți care erau aduși în grupuri organizate la teatru. De un succes real se bucurau spectacolele de operă și operetă care, firește, nu puteau fi atât de puternic ideologizate. De regulă, pentru a obține un bilet la un astfel de spectacol, trebuia să cumperi trei bilete la teatru unde se juca o piesă din repertoriul nou, românesc sau rusesc.

Planul de încasări se stabilea, în general, în funcție de numărul locurilor disponibile la sediu (610 în cazul Sălii Mari a Palatului Culturii din Târgu Mureș) și de numărul spectacolelor susținute la sediu și în deplasare. Din Centralizatorul planului cultural pentru anul 1963, secțiile română și maghiară, semnat de Tompa Miklós, rezultă că Teatrul de Stat din Târgu Mureș își propusese: 12 premiere cu 5 piese originale și 446 de reprezentații (216 la sediu și 180 în deplasare) cu 172364 spectatori, care ar fi adus încasări de 971116 lei. ${ }^{12}$ La rândul

comunism (I), în: http://www.arhivelenationale.ro/images/custom/ image/serban/RA\%201\%202009/15\%20catalan,\%20gabriel.pdf.

12. S.J.A.N.-Mureș, fond Sfatul Popular al Regiunii Autonome 
său, Teatrul de Stat de Păpuși propunea 5 premiere (2 piese originale), cu un total de 403 reprezentații (227 la sediu, 134 în deplasare, 42 în turneu), care ar fi adus 81000 de spectatori și un venit de 162250 lei. ${ }^{13}$

Un alt mijloc de a atrage spectatorii la piesele cu puternic conținut propagandistic era acela de a plasa în distribuție numele mari ale scenei românești din acea vreme: Ion Iancovescu, George Vraca, George Calboreanu, Grigore Vasiliu Birlic, Ion Finteșteanu, Radu Beligan, Maria Filotti etc. Unii din marii actori precum Constantin Radaman, Vichi Athanasiu sau Tanți Cocea au refuzat astfel de roluri, fiind treptat marginalizați. Actorii noi erau, la început, formați prin cursuri de scurtă durată și erau recrutați în funcție de devotamentul lor față de regim. După 1954, s-a renunțat totuși la această formulă și pregătirea actorilor a devenit mai profesionistă.

Regimul comunist îi atrăgea pe oamenii de teatru cu tot felul de avantaje materiale și simbolice, de statut social: distincții (ordine, medalii, titluri, ca „Ordinul Muncii“, „Medalia Muncii“, „artist al poporului“, „artist emerit al RPR“ etc.), diplome de absolvire a cursurilor Universității Serale de Partid (la Iași, de pildă, 35 de actori, membri sau nemembri ai PMR, urmau aceste cursuri în 1953), calitatea de membri ai Consiliului Artistic al Teatrului sau cea de participant la „Cercul Stanislavski“ din teatrul respectiv, cerc controlat ideologic de Partid prin Biroul Organizației de Bază, o funcție de conducere în acesta reprezentând, adesea, garanția succesului în cariera artistică și politică.

După cum arată documente deja publicate despre cenzura în teatru sub comunism, în primii ani, partidulîncepea supravegherea artistului din faza incipientă, organizând discuții între scriitori și activiști pentru angajarea temei viitoarei opere. Odată creată, aceasta era supusă examenului ideologic sever al diverselor comisii (cum au fost Comitetul de Lectură din Ministerul Artelor și Informațiilor, în 1948-1949, apoi Direcția Generală pentru Presă și Tipărituri,

Maghiare, dosar 301, f. 14.

13. Idem, f. 17. 
organism înființat pe lîngă Consiliul de Miniștri și care a funcționat din 1949 până în 1977, când atribuțiile sale au fost transferate spre redacții, edituri și conducerile teatrelor). Repertoriul era impus prin Direcția/Consiliul Teatrelor din Ministerul Culturii (mai târziu, Comitetul de Stat pentru Cultură și Artă, apoi Consiliul Culturii și Educației Socialiste, sub ultima titulatură). Inițiativa teatrului în fixarea propriului repertoriu a evoluat între limite strict controlate. La începutul anilor '50, fiecare teatru primea, pentru o stagiune (uneori doar pentru o jumătate de stagiune), lista pieselor pe care era obligat să le joace. Nu era permisă nici măcar schimbarea ordinii acestora.

O oarecare „relaxare“ a cenzurii s-a înregistrat la mijlocul deceniului șase al secolului al XX-lea, sub impulsurile date de „spiritul Genevei“ și de „raportul secret“ citit de N. S. Hrușciov la Congresul al XX-lea al PCUS (prin care erau dezvăluite și criticate unele crime și excese staliniste și cultul personalității lui Stalin), astfel că, din aprilie 1956, sub egida Ministerului Culturii și a Uniunii Scriitorilor, a fost publicată revista de specialitate Teatru, condusă de Camil Petrescu (în calitate de președinte) și Horia Deleanu (redactor șef).

De asemenea, contactele teatrale cu Occidentul (mereu considerat imperialist, decadent și cosmopolit) au fost reluate abia în iunie-iulie 1956, atunci când Teatrul Național din București a participat la Festivalul Internaţional de Artă Dramatică de la Paris, prilej cu care Partidul și Securitatea au încercat influențarea pozitivă, manipularea, dezinformarea și chiar readucerea în țară (măcar în vizită) a unor mari intelectuali români exilați (printre care actrițele Elvira Popescu și Alice Cocea, dramaturgul Eugen Ionescu, actorul Jean Yonnel, compozitorul și dirijorul Ion Perlea, sculptorul Constantin Brâncuși, scriitorii Mircea Eliade și Emil Cioran, ziariștii V. Alexandrescu, I. Velicu și R. Boilă), prin folosirea unor actori, regizori și scenariști ca agenți de influență (Marietta Sadova, Ion Manolescu, Maria Filotti, Sică Alexandrescu, Radu Beligan, Ion Henter ș. a.).

Ca o concluzie, putem afirma că, în perioada 1945-1964, teatrul, cu toate caracteristicile sale, a fost infestat de doctrina materialismului dialectic și istoric, a fost monopolizat de metodele, operele și canoanele realist-socialiste, i s-au 
impregnat dogmele luptei de clasă și ale decadenței artistice generalizate din lumea capitalistă, i-au fost impuse modelul sovietic, antiformalismul și anticosmopolitismul, fiind astfel transformat încât să contribuie eficient la făurirea „omului nou“.

Perioada 1965-1971 este cunoscută sub numele de perioada de deschidere culturală și de liberalizare politică. Este perioada în care sunt redescoperite și revalorificate filoanele naționale ale culturii, în care se reiau contactele intelectuale cu lumea occidentală; arta și activitățile culturale își revendică și obțin o relativă autonomie față de directivele politicii oficiale, directive ce cunosc și ele o fază de relaxare, iar cenzura ideologică devine mai permisivă. Artele plastice, teatrul, cinematografia, literatura și presa culturală cunosc o înnoire de substanță, o diversificare stilistică și realizări de performanță.

Distanțarea ideologică față de canoanele proletcultismului și ale „realismului socialist“ favorizează apariția unei noi generații artistice, care se va impune cu realizări de performanță, în toate domeniile, de la poezie, roman, critică și dramaturgie, la muzică, film, teatru, pictură și sculptură. În artele plastice și în mișcarea teatrală, în muzică și cinematografie, apar opere de valoare, sunt asimilate noile formule literare occidentale, critica literară dobândește un fundament teoretic solid, își înnoiește radical limbajul, abordările, stilul, scara de valori este refăcută după criterii estetice, sunt eliminate erorile și aprecierile aberante din anii proletcultismului.

„Ceea ce i-ar putea uimi pe tinerii de astăzi interesați de fenomenul «literaturii sub comunism» este faptul că mulți dintre scriitorii de care s-a servit propaganda până în ultima clipă a regimului nu au resimțit ca pe un moment excepțional al destinului literaturii române și ca pe o descătușare hotărârea Partidului de a nu-i mai constrânge pe scriitori să se supună schemelor realismului socialist“" (Negrici 2019, p. 267), remarcă profesorul Eugen Negrici de la Universitatea din București.

În general, are loc o diversificare a câmpului cultural, apar grupări care promovează anumite stiluri, reviste care se individualizează prin promovarea unor direcții și programe estetice, unii intelectuali, scăpați din închisori, încep să publice 
în reviste, alții sunt treptat integrați în învățământ sau cercetare. În principalele centre de județ, apar reviste culturale de ținută, în care se exprimă o nouă generație de intelectuali, detașați de dogmatismul marxist, cu referințe la modelele teoretice contemporane.

După 1971, în epoca minirevoluției culturale importate din China și Coreea de Nord, regimul comunist manifestă o tendință tot mai accentuată de reideologizare a mediului cultural și de înăsprire a cenzurii. Regimul politic evoluează treptat spre o restalinizare, prin impunerea unei „linii ideologice“ în cultură și prin cultul personalității dictatorului Ceaușescu. Efectul acestei cotituri ideologice este contradictoriu în plan cultural. În acest moment, se naște și o reacție, difuză, la început, de opoziție la politica regimului. Apar tot mai frecvent forme de protest social și intelectual. Mediile culturale aveau acum structuri consolidate, independente de cele politice, iar pozițiile dobândite de o serie de personalități și de unele publicații în perioada anterioară încurajează unele acte de dizidență individuală, care se vor amplifica în anii '80.

Mediile culturale sunt divizate, însă, de angajări teoretice și ideologice diferite, inclusiv de atitudini diferite față de tradiția culturală; sunt reluate teme și dispute din perioada interbelică. Literatura dezvăluie aberațiile sistemului comunist, dar într-un limbaj simbolic, aluziv și „esopic“, pentru a putea trece de cenzură. În mediile sociale și intelectuale, se dezvoltă un limbaj codificat prin care oamenii își exprimă aversiunea față de regim; este epoca limbajului dublu, a unor conduite duplicitare, ca strategii de supraviețuire și de opoziție simbolică.

Este perioada în care cenzura se înăsprește, repertoriile sunt din nou controlate strict, circuitul informației este supravegheat. Dar, deși propaganda s-a intensificat, ea nu mai avea eficiența dorită, regimul nu mai era crezut, iar lumea culturală a opus diverse forme de rezistență, pasive sau manifeste.

La începutul anilor' 80 ai secolului trecut, teatrele, ca de altfel toate instituțiile de cultură, în afară de biblioteci, au fost lovite de aberantele măsuri ale programului de autofinanțare impuse de un regim cu o economie aflată în plină degringoladă.

Proiectele optimiste ale conducerilor s-au văzut minate de reducerea treptată a sumelor alocate de la buget, începand cu 
1 aprilie 1984. Subvenția pe care o primea Teatrul Național din Târgu Mureș, de pildă, era, uneori, mai mică decât asigurările sociale și impozitele pe care instituția trebuia să le achite statului $^{14}$. În asemenea condiții, instituția s-a văzut pusă în fața unei probleme capitale - cea a supraviețuirii sale, prin măsuri de economii extreme și prin recurgerea la diferite soluții paliative. Pentru a se putea încadra în limitele financiare impuse, era necesară aplicarea unui regim sever de economii, sporirea numărului de abonamente, prestarea de servicii către populație, închirieri de costume pentru petreceri, confecționarea de reclame pentru diferite unități economice etc.

$\mathrm{Cu}$ sprijinul Comitetului Județean de Cultură și Educație Socialistă, acesta a elaborat, împreună cu întreprinderile economice patronatoare, programe anuale de acțiuni comune vizând realizarea de spectacole, manifestări cultural-artistice și distractive, eficiente financiar; au fost luate măsuri concrete pentru sporirea numărului și a calității spectacolelor (pentru atragerea a cât mai mulți spectatori); organizarea unor spectacole de mare amploare pe stadioane și în alte spații naturale etc.

„Și totuși - continua Iuliu Moldovan - s-au găsit oameni de suflet care au fost alături de teatru cu sufletul și cu... banii, al căror nume ar merita consemnat în cronica teatrului... Și au fost niște spectatori care umpleau sălile, răsplătind generos valurile de transpirație de pe scenă. Au fost..." (Fodor 2002, pp. 225-226).

14. Iuliu Moldovan, care a deținut două mandate de director al Naționalului târgumureșean (1973-1976 și 1985-1991) spunea că: ,... A urmat «al doilea mandat», între 1985-1991, cea mai «obsedantă perioadă» din istoria de până atunci a teatrului românesc. Finanțare de doar $15 \%$, vizionări repetate ale unor spectacole de către faimoasa comisie ideologică, frica de a nu evada din «indicațiile tovarășului», emoții până la aprobarea repertoriului de către «tovarășa de renume mondial», teama de a nu putea achita salariile etc". (apud Zeno Fodor, Teatrul românesc la Târgu Mureș, volum aniversar, p. 225). 


\section{Bibliografie:}

Burakowski, Adam, Dictatura lui Nicolae Ceaușescu 1965-1989. Geniul Carpaților, traducere de Vasile Moga, prefață de Stejărel Olaru, Iași, Editura Polirom, 2011.

COMISIA prezidențială pentru analiza dictaturii comuniste din România, Raport Final, București, Editura Humanitas, 2007.

CulCER, Dan, Cenzură și ideologie în comunismul real, vol. 1, Cluj-Napoca, Editura Argonaut, 2016.

FAURE, Élie, Istoria artei. Spiritul formelor, traducere de Irina Mavrodin, prefață de Dan Grigorescu, vol.1, București, Editura Meridiane, 1990.

BuȘE, Daniela; MARINESCU, Beatrice; RĂDULESCU-ZONER, Șerban, Instaurarea totalitarismului comunist în România, București, Editura Cavallioti, 1995.

Fodor, Zeno, Teatrul românesc la Târgu Mureș, volum aniversar, Târgu Mureș, Teatrul Național, 2002.

Mazower, Mark, Umbre peste Europa. Democrație și totalitarism în secolul XX, traducere din limba engleză de Mihnea Gafița, București, Editura Litera, 2019.

MıŁosz, Czesław, Gândirea captivă, traducere din polonă de Constantin Geambașu, postfață de Włodzimierz Bolecki, București, Editura Humanitas, 2017.

NEGRICI, Eugen, Literatura română sub comunism, ediția a III-a revăzută și adăugită, Iași, Editura Polirom, 2019.

SELEJAN, Ana, România în timpul primului război cultural (19441948), vol. II: Reeducare și prigoană, Sibiu, Editura Transpres, 1993. 